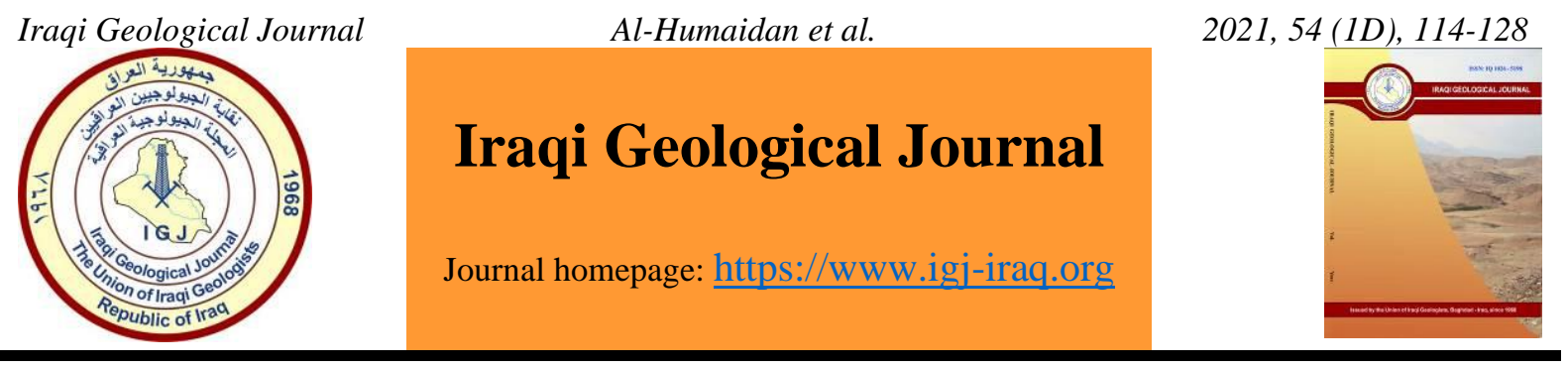

\title{
A Study of Fauna Assemblages and Their Relation to the Sediment Accumulation in the Coral Reef Area, NW of the Arabian Gulf
}

\author{
Zainab A. Al-Humaidan ${ }^{1}$, Nada S. Al-Zlemat ${ }^{2}$, Usama Q. Khaleefah ${ }^{2}$ and Lamees S. Al-Qurnawy ${ }^{1}$ \\ ${ }^{1}$ Department of Sediments, Marine Sciences Center, University of Basrah, Basrah, Iraq \\ ${ }^{2}$ Department of Applied, Marine Sciences Collage, University of Basrah, Basrah, Iraq \\ * Correspondence: alwhaely72@gmail.com
}

Received: 18 July 2020; Accepted: 1 February 2021; Published :30 April 2021

\begin{abstract}
The discovery of coral reefs in Iraqi marine waters is a new event in 2012 and it covers an area of approximately $28 \mathrm{~km}^{2}$ at the southern end of Khor Al-Amia. A team of divers from the German Freiburg Institute for Mining and Technology and Marine Science Center at the University of Basra were able to find coral reefs in the NW part of the Arabian Gulf. The aim of this article is to study fauna assemblages and try to understand the relationship between the accumulation of sediments and fauna assemblages in the Coral Reef area NW of the Arabian Gulf, southern of Iraq. Four surface samples of sediments of the area were studied and determined the relationship between the types of texture and the amount of fauna and shell fragments. Mollusca was chosen from among the existing groups of fauna due to the great number of species and large sizes, also Bryozoa studied in the region. The sand texture is predominant in the sediments of the area and the sand ratio was between 55-97\% most of their grains are fine and round. The sediments of the region were distinguished by a high percentage of shells between 24-69\% from the total percentage of sand. The phenomenon of multiple colors of sand and fauna revealed this due to the presence of minerals and oxides, impurities and pollution in the region, and genetic factors concerning fauna. Many species were diagnosed in the sediments of the region, reaching 62 species of Mollusca and Bryozoa. Mollusca is classified into three types (Gastropod, Pelecypoda and Scaphopoda). Some species were recorded for the first time in the region such as Japonactaeonpusillus, Cylichna cylindracea and Cuna majeeda.
\end{abstract}

Keywords: Fauna; Marine sediments; Coral reef; Palinurus; shells; Arabian Gulf

\section{Introduction}

Coral reefs are distributed within an area of $28 \mathrm{~km}^{2}$, and the area is characterized by different depths compared to neighboring areas, where the depth ranges (7-20m) (Pohel et al. 2014). Palinurus shoal is considered Coral reefs area and one of the shallow sites in Iraqi marine waters and defined as underwater structures. The shallow depths represent semi-underwater islands confined within the great depths of the Khor, they appear as an anomaly within the Khor, which are impermeable morphological structures that found in shallow marine environments, it forms a strip of $58 \mathrm{~km}$ from the northern coast of the Arabian Gulf (Goudie, 2006). Coral reefs are among the greatest keys to unlock our understandings of a marine ecosystem (Perkol-Fenkel and Banayahu, 2007). Coral reefs of the Arabian Gulf and Oman Sea are serious habitats of cultural, socio-economic, and scientific importance. Coral reefs are defined as underwater structures made of calcium carbonate that is excreted by corals, they are formed from chemically unstable minerals, namely argonite and calcite, which can subsequently subjected to various chemical changes (Selley, 1982). The results of Sub Bottom Profiler (SBP) show DOI: 10.46717/igj.54.1D.10Ms-2021-04-30 
that the study site is representing a hard bottom shallow structure, one of the patterns on the sea bottom (P2) pattern of relative strong backscatter that appears in the north of the SSS map, it corresponds of coarse and medium sand with shells fragments more than carbonates rocks (Al-Mosawi, 2015). Corals particularly in the Arabian Gulf are exposed to great summer sea temperatures compared with other tropical regions, with temperatures for several months annually and summer maxima rising above $36^{\circ} \mathrm{C}$ (Coles and Riegl, 2013; Burt et al. 2015). Al-Zlemat (2019) explained that area consists of calcium carbonate that is excreted by corals are formed from chemically unstable minerals, namely calcite, aragonite and other minerals like quartz, etc. Sand was prevalent in the sediments of the region and includes shell fragments in various sizes. The diversity in species is very wide especially in the marine environment represented in the open sea near Basra's Deep Port and some species have the first record in the study area (Al-Humaidan, 2018). Al-Jaberi and Mahdi (2020) Studied the fauna in sediments of Karmat Ali, and mentioned that the Foraminifera, ostracods, mollusca, and radiolarian are most of the fossils in the study area. The aim of this article is to study fauna assemblages and try to understand the relationship between the accumulation of sediments and fauna assemblages in the Coral Reef area NW of the Arabian Gulf, south of Iraq

\section{Materials and Methods}

In this paper four sites of marine sediments were collected for the area. This area is located northwest of the Arabian Gulf near the Khor al-Khafqa south of Iraq. It confined between two lines of

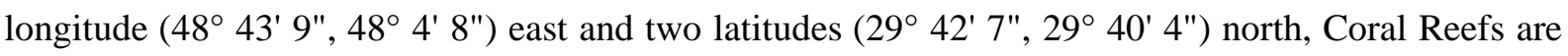
distributed within an area of $28 \mathrm{~km}$ (Table 1) and (Fig.1)

Table 1. Longitude and Latitude of samples in study area

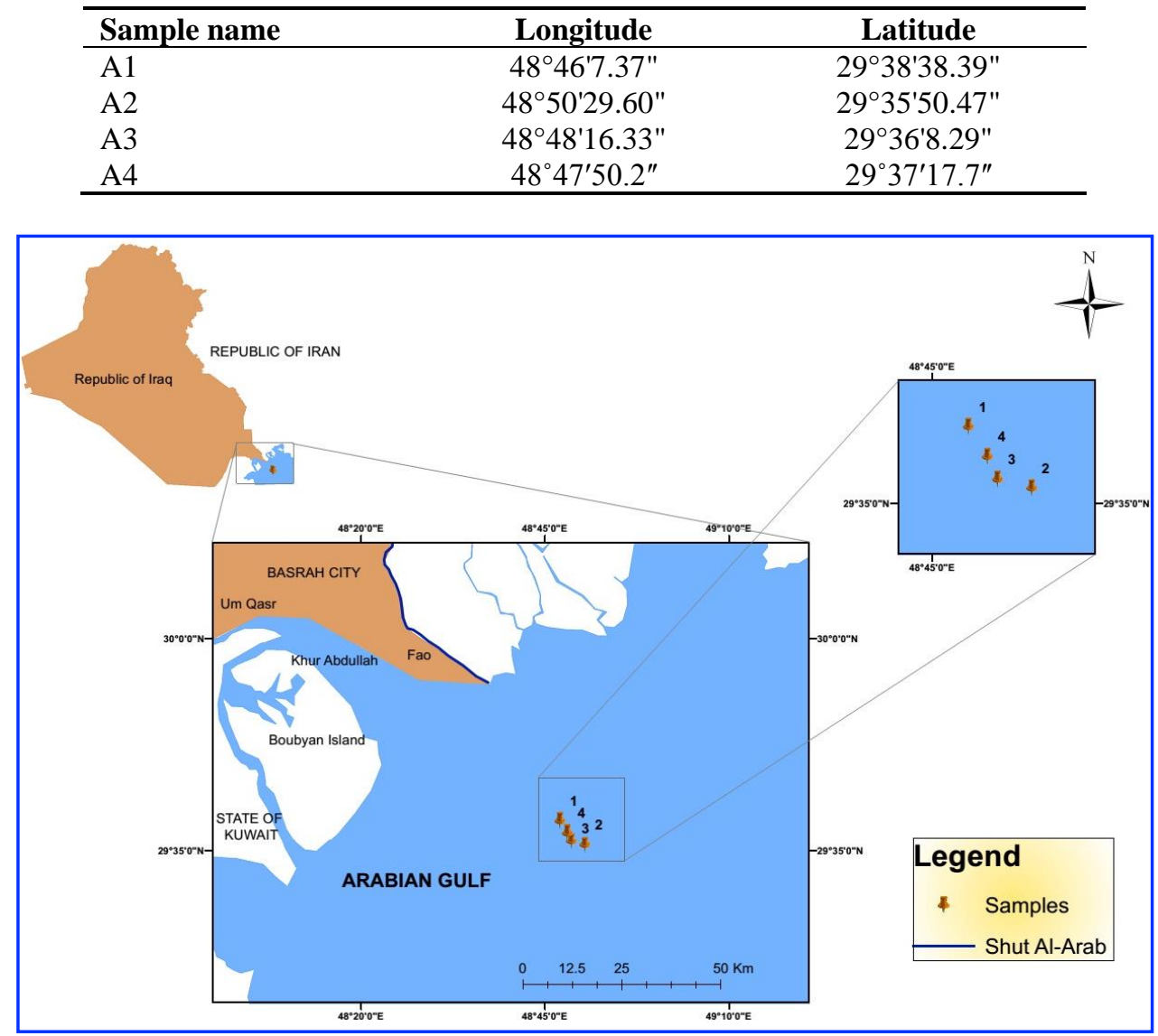

Fig. 1. Map of the study area 
The scientific team at the Marine Science Center made a trip to the Palinorus shoal region on a ship (The Researcher). Four specimens from marine sediments are selected in four sites in the Iraqi coral reefs area and were studied from the sedimentological and micro fauna side and the relationship between them include several local of Palinurus shoal region, sediments samples were taken by the sediment collection device (Grape Sampler). Fifty grams of the dried sample was washed with a $0.063 \mathrm{~mm}$ sieve in wet sieving with distilled water carefully to preserve biogenic organic sediment and dry the remaining part in the sieve in drying Oven on $105^{\circ} \mathrm{C}$. Fauna in the sediments was diagnosed in addition to the effect of grains texture on them. The grains size of sediments and the type of texture calculated by the Pipette method according to Folk (1974). Fauna in sediments are picking under a microscope with a special brush and then sorted and classified species and genera, all species and genera are taken under the microscope are depicted with a special camera to classify them. Identification of fauna in this study is based on the latest approved systematic classification established by Keen and Coan (1974) and Moore (1969) for Mollusca. The samples sieved in three sizes of sieves $(0.125,0.250$ and $0.500 \mathrm{~mm})$, the great weights of fauna and sand were on $0.500 \mathrm{~mm}$ sieve (Table 2).

Table 2. The percentage of sand and shells in different sizes

\begin{tabular}{cccc}
\hline Sample name & Sieve 0.500mm \% & Sieve 0.250mm \% & Sieve 0.125mm \% \\
\hline A 1 & 42 & 14 & 44 \\
A 2 & 16 & 32 & 52 \\
A 3 & 68 & 21 & 11 \\
A 4 & 72 & 12 & 16 \\
\hline
\end{tabular}

\section{Discussion and Results}

The study deals with the relationship between fauna and the sediments present with it, and it was noticed during the research under the microscope the difference of sediment colors, especially sand and fauna. The color of sediments is light, olive to grey indicating anaerobic and quiet environment conditions (Al- Sudani, 2015). Also, Al-Humaidan (2018) indicated that sand and fauna colors in the Arabian Gulf region near the deep port of Basra were dark colors due to the processes of reduction in sediments. The percentage of carbonates in the region was very high between 14-72\% (Al-Zlemat, 2019). This is considered one of the conditions for this fauna to live and reproduce as well as physical, hydrological, and depth, these factors are important in carbonate precipitation in this region. In addition, there is a positive relationship between the quantity of shells and the percentage of $\mathrm{CaCO}_{3} \%$ where the amount of shells increased with increasing of $\mathrm{CaCO}_{3} \%$ and depth, and this is confirmed by White et al. (2007) which explained that the Mollusca shells consist of 95-99\% $\mathrm{CaCO}_{3}$.The sediment texture and the percentages of sand, silt and clay were present in Table 3, and the sand percentage were high between $55-97 \%$. Al-Ghadban (1980) proved that the increase in organic matter is due to the abundance of shell fragments. These shells cause a change in the size of the sediments and may reach this size to the sand or gravel; this is an important factor in increasing calcium carbonate, regardless if the sediments are sandy or silty.

Table 3. Grain size analysis and texture

\begin{tabular}{cccccc}
\hline NO. & Sample name & Sand \% & Silt \% & Clay \% & Texture \\
\hline 1 & A 1 & 55 & 35 & 10 & Sandy silt \\
2 & A 2 & 97 & 3 & 0 & Sand \\
3 & A 3 & 97 & 2 & 1 & Sand \\
4 & A 4 & 96 & 3 & 1 & Sand \\
\hline
\end{tabular}

According to the study under the microscope, it showed that the grains of sand from roundness to sub-roundness, and this is evidence of the continuous and strong currents in the region. This is consistent 
with (Khalifa (2019). After picking fauna, the clean sand free from the shell fragments has been isolated and the percentage of the shells and clean sand has been calculated as in Table 4.

Table 4. Weights percentages of sand and shells

\begin{tabular}{lccccc}
\hline $\begin{array}{l}\text { Sample } \\
\text { name }\end{array}$ & Sand \% & $\begin{array}{c}\text { Pure } \\
\text { sand \% }\end{array}$ & $\begin{array}{c}\text { Total of } \\
\text { shells \% }\end{array}$ & $\begin{array}{c}\text { Shell } \\
\text { fragments \% }\end{array}$ & $\begin{array}{c}\text { Fauna } \\
\text { unbreakable \% }\end{array}$ \\
\hline A1 & 55 & 31 & 24 & 23 & 1 \\
A 2 & 97 & 71 & 26 & 20 & 6 \\
A 3 & 97 & 38 & 59 & 50 & 9 \\
A 4 & 96 & 27 & 69 & 60 & 9 \\
\hline
\end{tabular}

The results showed that the average of shells was significant compared to sand, as the ratio reached $69 \%$ in sample A4, and this indicates the availability of suitable environmental conditions for fauna, Fig. 2 explains the ratio of pure sand and shell fragments. The sediments contain a quantity of broken shells emphasize their deposition under the lagoon and beach environments (Varghese, 2014).

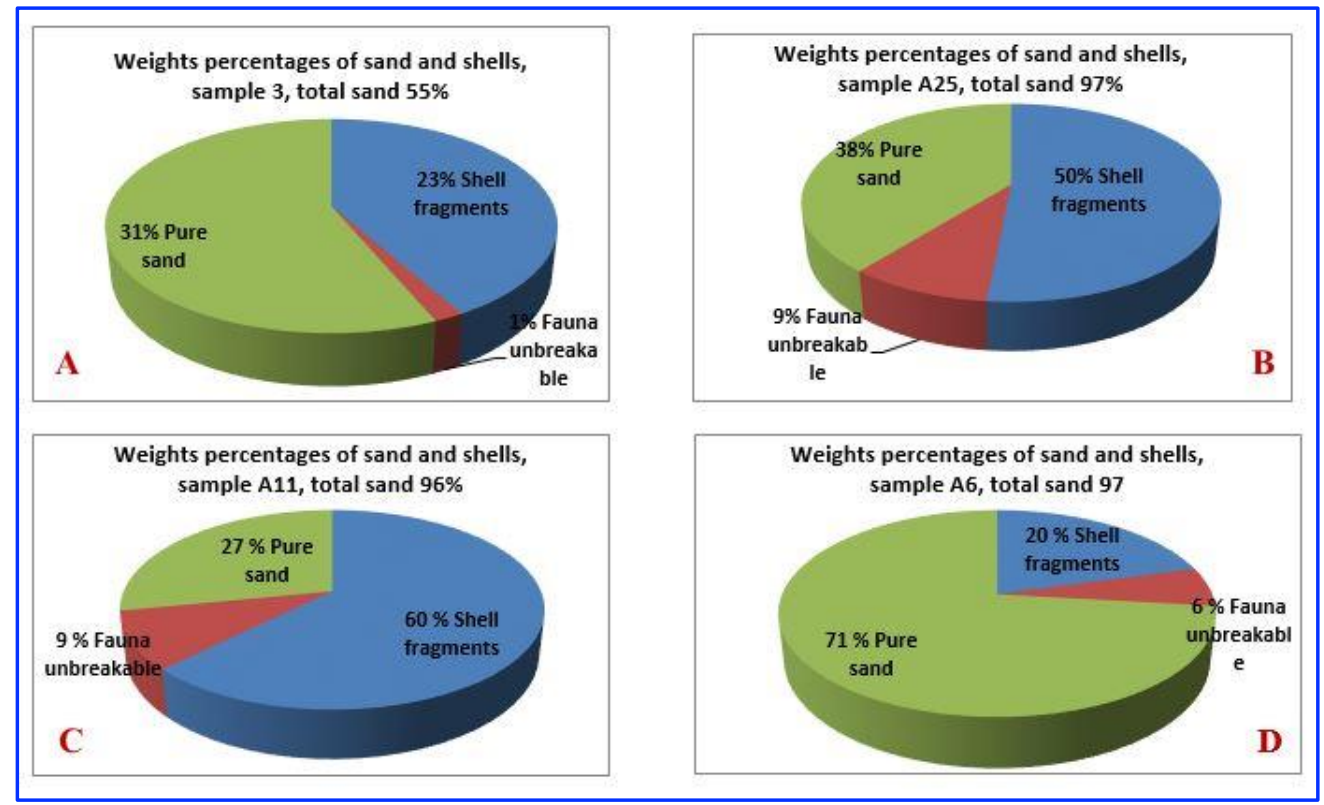

Fig. 2. The percentages of shells and pure sand in samples

\subsection{The Environmental Effects on Fauna and Sediments Accumulation}

Marine environmental factors are very important in determination the type of sediments, their sizes and the types of minerals deposited with them. In addition, these factors determine the amount of fauna, the diversity in the species and its growth. These factors result in an encouraging ecosystem for the emergence and deposition of distinctive sediments with the growth and reproduction of fauna. These factors are: $\mathrm{pH}$, salinity, depth, temperature, organic carbon and calcium carbonate. These factors have been measured in the field by the scientific team at the Marine Sciences Center and also in the center's laboratories (Table 5).

\subsubsection{Water salinity}

The Arabian Gulf is a specific basin due to the water exchange with the Indian Ocean across the Strait of Hormuz. It is normal for high temperatures to affect the water and increase its salinity, and the lack of discharge from the Tigris and Euphrates rivers increased the tidal front coming from the Gulf (Karim and Salman, 1988).The overall salinity rate in the region for the range of salinity was (44.0 $37.5 \%$ ) (Al-Zlemat, 2019).The salinity and texture of sediment are the main factors that control the 
ecology and distribution of recent fauna, where it was found that the percentage of sand increases with increasing salinity (Shareef et al. 2015).

\subsubsection{Water temperature}

The temperature fluctuates in the waters of the Palinorus region, and the total of water temperature over the measured months is $24.8^{\circ} \mathrm{C}$ (Table 5). This temperature affects metabolic rates, dissolved oxygen, concentrations of dissolved gases, salinity, water density, etc. All of these effects created the conditions for a clear reproduction and gathering of fauna.

\subsection{3. $\mathrm{pH}$}

$\mathrm{pH}$ increases with a decrease or removal of $\mathrm{CO} 2$ by the process of photosynthesis of algae; this reduces acidity and affects the increase in the sedimentation of calcium carbonate (Boggs, 2006). This is evidence of the increased shells in the sediments of the region. $\mathrm{pH}$ values in the region ranged between 7.69 - 8.97 (Table )5.

\subsubsection{Depth}

Depth affects deposition and melting of minerals and is a function of many factors, such as the temperature which varies with increasing depth and these effects on sedimentation processes. The area is characterized by its shallow water and this reflects an increase in the levels of calcium carbonate sedimentation (Boggs, 2006). The average depth of water in the area was $9.9 \mathrm{~m}$ (Table 5).

Table 5. Extent and average environmental characteristics of the region 2018 according Al-Zlemat (2019)

\begin{tabular}{lccccccc}
\hline $\begin{array}{l}\text { Environmental } \\
\text { factors }\end{array}$ & $\mathbf{2 4 / 2 / 2 0 1 8}$ & $\mathbf{2 4 / 2 / 2 0 1 8}$ & $\mathbf{2 4 / 2 / 2 0 1 8}$ & $\mathbf{2 4 / 2 / 2 0 1 8}$ & $\mathbf{2 4 / 2 / 2 0 1 8}$ & $\mathbf{2 4 / 2 / 2 0 1 8}$ & $\mathbf{2 4 / 2 / 2 0 1 8}$ \\
\hline Water temp ${ }^{\circ} \mathrm{C}$ & 17.8 & 19.5 & 24.0 & 27.0 & 29.0 & 31.7 & 24.8 \\
pH & 8.84 & 8.8 & 8.23 & 7.6 & 8.97 & 8.49 & 8.4 \\
Salinity (PPt.) & 44.0 & 43.0 & 37.5 & 39.0 & 42.24 & 41.0 & 41.1 \\
EC (MS/cm) & 66.7 & 66.4 & 58.2 & 59.8 & 66.0 & 63.8 & 63.5 \\
TSS (mg/l) & 0.09 & 0.09 & 0.04 & 0.07 & 0.08 & 0.07 & 0.07 \\
TDS (mg/l) & 40000 & 39800 & 37300 & 38300 & 39700 & 38200 & 38883 \\
Depth (m) & 7.5 & 10.0 & 8.0 & 10.0 & 15.0 & 9.0 & 9.9 \\
Transparency $(\mathrm{cm})$ & 140 & 145 & 150 & 110 & 140 & 200 & 147.5 \\
\hline
\end{tabular}

\subsection{Causes of Various Colors of Sand Sediments}

Color is one of the most obvious properties of sediment, color is sensitive to present conditions on the bottom such as depth of water, Eh, and $\mathrm{pH}$, to the texture and mineral composition, and other components such as disseminated organic matter, bacteria, and carbonate. Environmental, bacterial and organic pollution in water and marine sediments is also an important factor in sand and fauna coloring (Claisse, 1989). In the study area one of the most important notes on the sand is the complete roundness of most grains in the region, classified as roundness to sub-roundness. The study of fauna and sand under a microscope showed great diversity in sand colors, as well as fauna. The sand found in the area was distinguished by many colors: transparent white, yellow, orange, brown and black (Fig. 3). Stanley (1969) was mentioned in his study and previous studies, the reasons for the change in sand colors including: Secondary effects of rock destruction, climatic conditions and patterns of sediment transportation on the intrinsic colors of the mineral and rock fragments, size of sediment particles and the closeness of their source, genuine colors of the minerals or rock fragments of which the sample is composed, percentage of hydration of iron compounds and the rate of iron in clay minerals, conditions 
at the site of deposition, including the amount and kind of organic matter present and the degree of oxidation or reduction of pigment at and just below the sediment-water, diagenesis during and following deposition of sediments.

According to Al-Zlemat (2019), the iron oxide minerals represent a large percentage of heavy metals in the Palinorus region in the range (38.4\%-45.3\%), and explained that the organic matter in the sediments has an important role in affecting the color of the sand, as the range of organic carbon in the region is $1.73 .5 \%$. Iron oxides, which include hematite (red), limonite (yellow) and magnetite (black), have a major effect on the coloration of sand and fauna (Fig. 4).

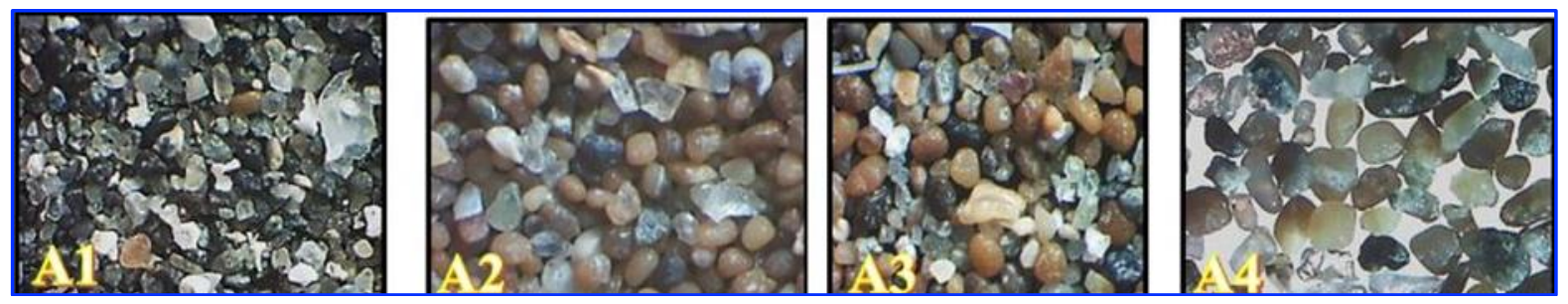

Fig. 3. Colors of sand in samples with different sites (A1-18X, A2-25X, A3-25X, A4-25X)

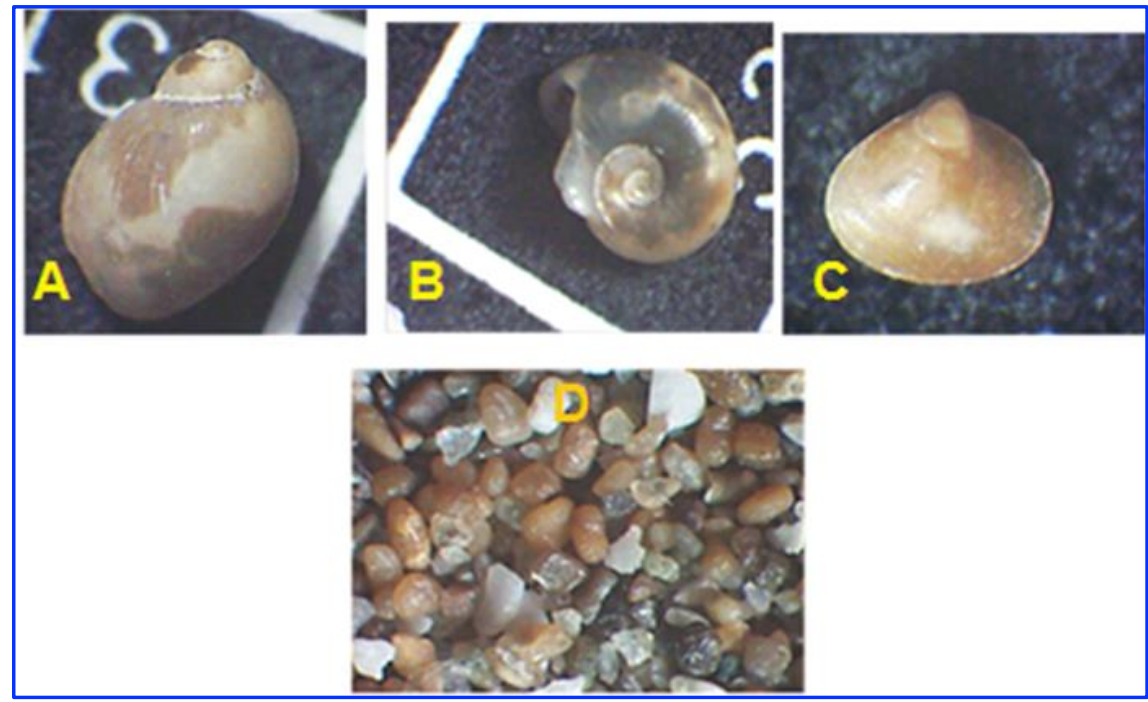

Fig. 4. Colors of fauna and sand (A-18X, B-18X, C- 40X, D-25X)

\subsection{Study of Shells in the Sediments}

Fauna was collected and picked under optical microscopy. The shells fragments are between 20$60 \%$ in sand, Table 3. Mollusca are classified into many species according to Table 6 and Fig. 5.

Table 6. Fauna and their Number Species

\begin{tabular}{lcc}
\hline No. & Fauna & Number of species \\
\hline 3 & Gastropoda & 28 \\
4 & Pelecypoda & 23 \\
5 & Scaphopoda & 5 \\
6 & Brayozoa & 6 \\
Total & & 62 \\
\hline
\end{tabular}




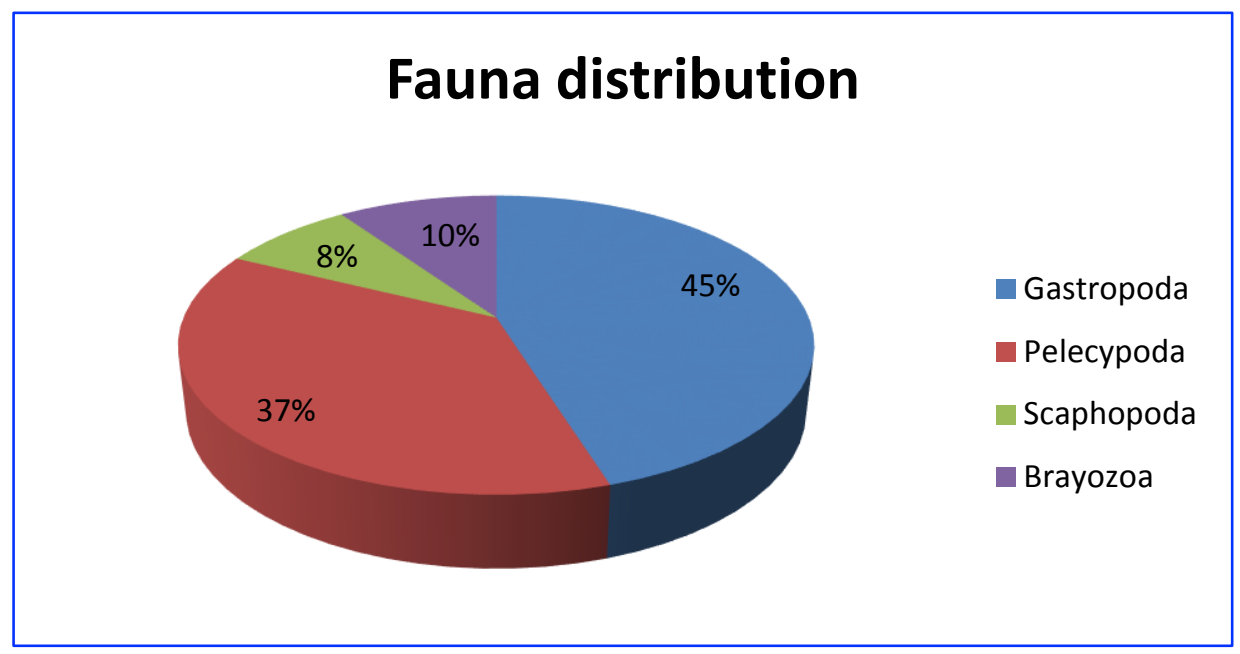

Fig. 5. Numbers of species in study area

Mollusca and Bryozoa in the sediments of the study area; there are three types of Mollusca, as followed: (Gastropoda, Pelecypoda and Scaphopoda) (Tables 7, 8, 9 and 10).

\subsubsection{Mollusca}

The most prevalent species and dominant in the study area are Mollusca. They are distinguished by their large sizes and broken shells. In the studied area Mollusca is classified into three main types as follows: Gastropoda, Pelecypoda and Scaphopoda. It has been reported by Boggs (2006) that most of the Mollusca are composed of aragonite, and that some of them consist of Calcium-Magnesium. As White et al (2007) explained that the Mollusca shells consist of (95-99) \% of calcite minerals. Rapid transport of dead shells into surrounding sediments or into crevices within corals is typical of gastropods that feed on corals. Molluscs that colonize dead surfaces preferentially accumulate on rock grounds (Zuschin et al. 2001).

\subsubsection{Gastropod}

It is commonly known as slugs and snails living in fresh and marine water, the higher productivity of water body that found in the northern part of the Arabian Gulf is due to the high variety of Gastropod (Shareef and Mahdi, 2015). About 28 species of Gastropod were diagnosed in the study area, and species were first recorded. Some of gastropod assemblage that dominate in the study area depend on the presence of porites, which is a species of coral that gastropod feeding on corals (Zuschin et al. 2001). Most of gastropod is a benthic moving on bottom and these fauna effect on the distribution and transport of sediments grains (Angela et al. 2000). The common species in the study area are: Bellamyabengalensis, Polynicesmamilla, Turbinellapyrum and Turbonillaobliquata (Plate 1 and Table 7).

\subsubsection{Pelecypoda}

Pelecypoda (Also called bivalve) was characterized by its wide variety and spread in the study area, most of Pelecypoda bury themselves in sediments, on the bottom of the sea and on hard rock surfaces or coral. Register with up to 23 species of Pelecypoda in study area, it was the most quantity compared to other classes, the most common of which are: Angulus , Bassinayatei, Carbulasubquadrata, Carditella pallid, Corbicula fluminalis, Dosinia Llaminata and Theora mesobotimia ( Plate 2 and Table 8). The shell of a Pelecypoda is composed of calcium carbonate and lives in fresh, marine and brackish environments (Al-Omari and Abadi, 1982). When they live in polluted waters, bivalve molluscs have a 
tendency to accumulate substances such as heavy metals and persistent organic pollutants in their tissues; it also has certain advantages in that bivalves can be used in monitoring the presence and quantity of pollutants in their environment (Burns and Smith, 1981). Several species were recorded and found in significant quantities in the study area. Moreover, it was found meddlesome on some species of Pelecypoda.

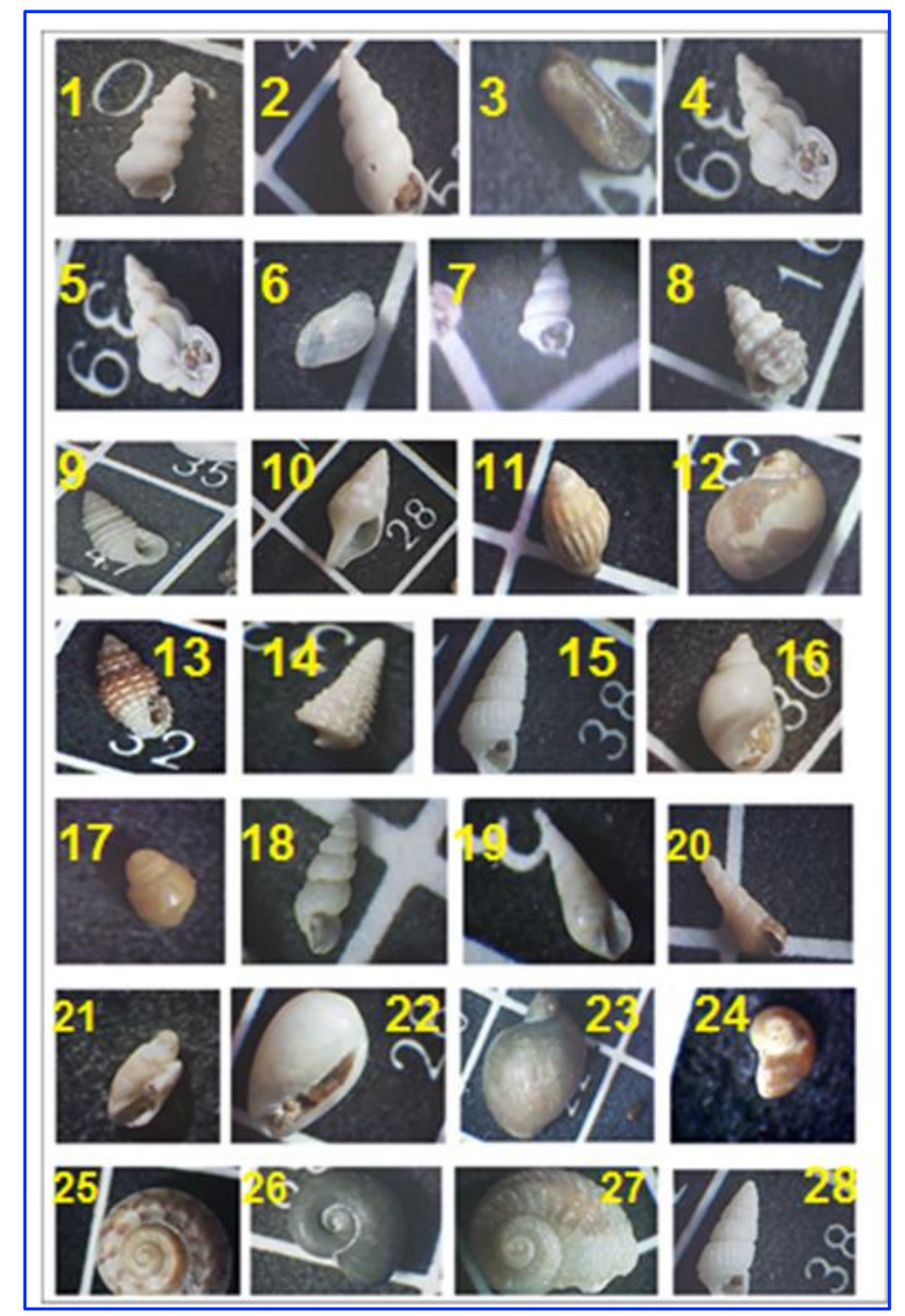

Plate 1. (Gastropoda)

1. Clathrofenella ferruginea (A. Adams, 1860) 18X 16. Polynices ampla (Gmelin) 40X

2. Pyramidellidae gen. sp. $18 \mathrm{X}$

3. Cylichna cylindracea(Pennant,1777) 40X

4. Epitonium apiculatum (Dall 1889) 25X

5. Gibborissoa virgate (Philippi, 1849) 25X

6. Japonactaeon pusillus (Forbes, 1844) $25 \mathrm{X}$

7. Calliostoma coppingeri (E.A.Smith,1880) 50X

8. Cerithidea fluviatillis (Potiez et Michaud)18X

9. Odostomia impressa ( Say, 1821) $12 \mathrm{X}$

10. Turbinella pyrum ( Linnaeus, 1767) $12 \mathrm{X}$

11. -Alvania rykelii (Risso, 1826) 18X

12. Bellamya bengalensis (Lamarck, 1822) $18 \mathrm{X}$

13 Aciculina sp. 18X

14. Cerithideopsilla conica (Blainville, 1829) $25 \mathrm{X}$

17. Polynices mamilla (Linnaeus, 1758) $40 \mathrm{X}$

18. Scaliola sp. $40 \mathrm{X}$

19. Terebra maculate (linnaeus 1758) 40X

20. Odostomia Serenei (Saurin, 1959). 25X

21. Retusa obtuse ( Montagu,1803) 18X

22. Gibberula granum (Philippi) $18 \mathrm{X}$

23. lymnaea tenera euphratica (Mousson) $12 \mathrm{X}$

24. Umbonium sp. $18 \mathrm{X}$

25. Umbonium vestiarium (Linneus) $15 \mathrm{X}$

26. Omalogyra atomus (Philippi,1841) 18X

27. Circulus striatus (Philippi, 1836) 18X

28. Turbonilla obliquata (Philippi, R.A., 1844) 18X

15. Turbonilla umbrina (Melvill, 1918) 40X 


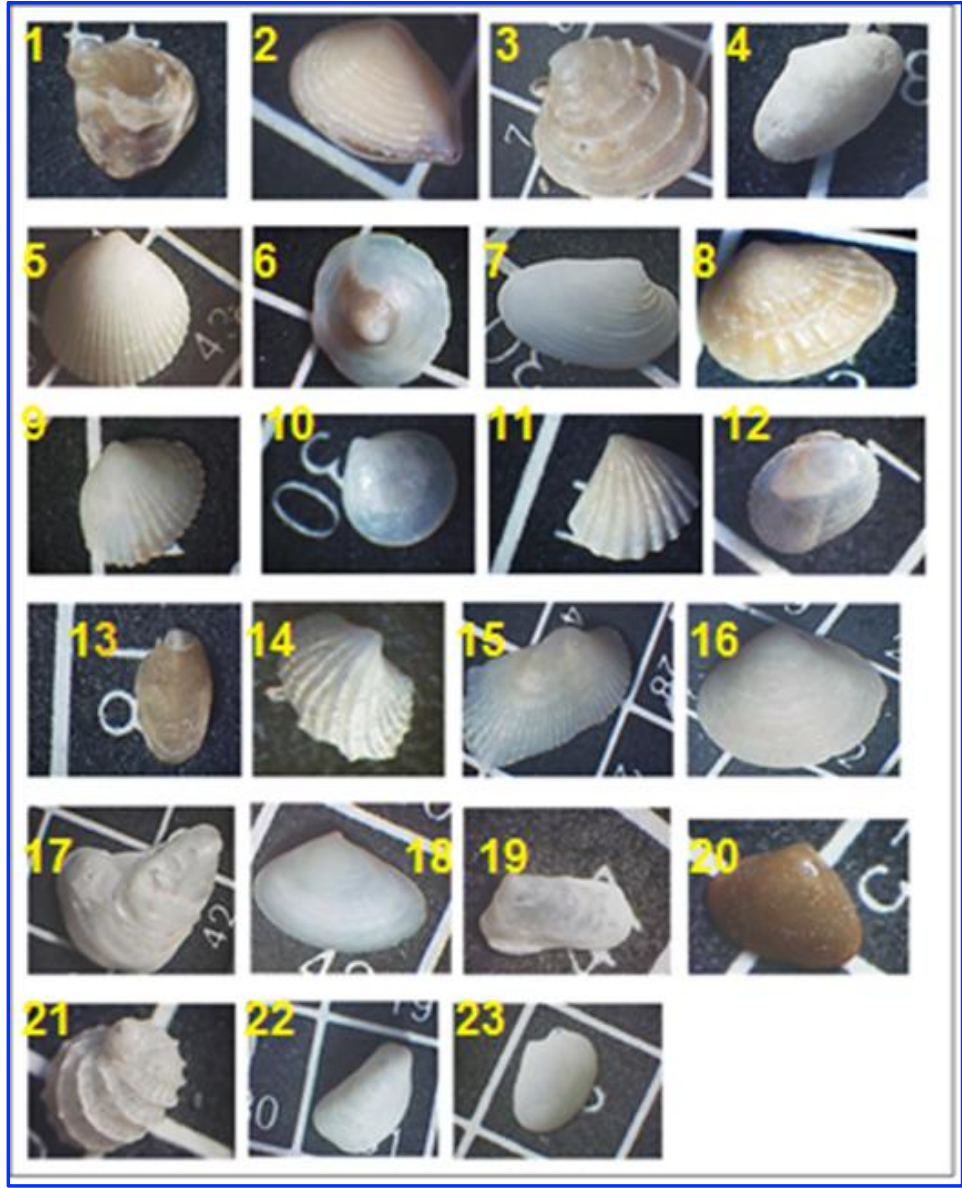

Plate 2. Pelecypoda

1. Crassostrea iridescens (Hanley, 1854), 10X

2. Corbula subquadrata (Melvill,1907) $18 \mathrm{X}$

3. Bassina yatei (Gray, 1835) 10X

4. Mactra sp. 12X

5. Vasticardium flavum (Linnaeus, 1758)

6. Calyptraea chinensis (Linnaeus 1758) $15 \mathrm{X}$

7. Dosinia Laminata (Reeve) $18 \mathrm{X}$

8. Cuna majeeda (Biggs, 1973)18X

9. Codakia orbicularis ( Linnaeus, 1758) $20 \mathrm{X}$

10. Kellia suborbicularis (Montagu, 1803) 25X

11. Carditella pallid (Smith, 1881),25X

12. Musculus niger (J.E.Gray,1824) $25 \mathrm{X}$
13. Vulsella vulsella (Linné,1758) $25 \mathrm{X}$

14. Striarca lactea (Linnaeus 1758) 40X

15. Bentharca sagrinata (Dall,1886) $9 \mathrm{X}$

16. Corbicula fluminalis (Muller) $9 \mathrm{X}$

17. Ostrea sp. $11 \mathrm{X}$

18. Theora mesobotimia (Annandale, 1918) $15 \mathrm{X}$

19. Hiatella artica (Linnaeus 1767) $25 \mathrm{X}$

20. Angulus sp 25X

21. Bassina callophyla (Philippi, 1836)25X

22. Brachyodontes variabilis (Krauss, 1848) $12 \mathrm{X}$

23. Tellina sp. $12 \mathrm{X}$

\subsubsection{Scaphopda}

This group has the lowest species in study area and belongs to Mollusca's in the study area, and it was diagnosed with the lowest number of species in the region, reaching only 5 and the most common are: Dentalium octangulatum and Dentalium quadrapicale (Plate 3 and Table 9). Scaphopods are all marine species; this indicates that the region is stabilizing due to the relative calm of the currents, from shallow sub-littoral areas.

\subsubsection{Bryozoa}

Bryozoans are an important part of the benthic marine fauna in a wide variety of modern environments and are found in rock forming (Hagemanet al. 1998). Bryozoa live as colonies in marine 
environments, with coral, Echinodermata, and Brachiopod, and abound in shallow, temperate or tropical coastal environments (Al-Omari and Abadi, 1982) (Plate 4 and Table 10).

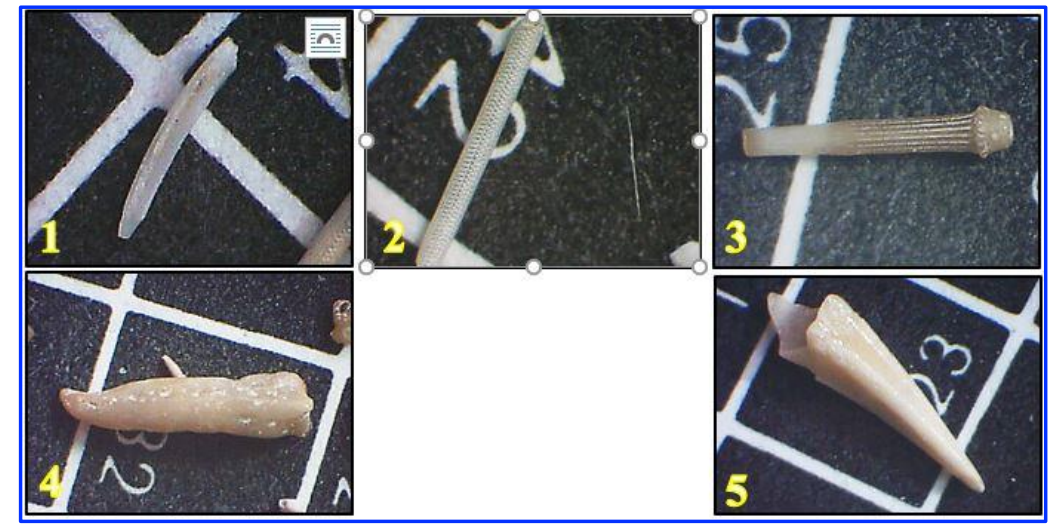

Plate 3. Scaphopoda

1-Dentalium octangulatum (Donovan, 1804) 25X

2-Dentalium diarrhox (R. B. Watson, 1879) 25X

3-Cidaris farringdonensis- urchin spine (Linnaeus, 1758) $18 \mathrm{X}$

4-Dentalium quadrapicale (Donovan, 1803) 25X

5-Dentalium sp. (Linnaeus, 1758) 12X

Table 7. Gastropoda Species distribution in the samples

\begin{tabular}{|c|c|c|c|c|c|}
\hline NO. & Sample No. & Z & $\underset{4}{2}$ & 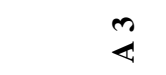 & $\underset{4}{+}$ \\
\hline & Species & & & & \\
\hline 1 & Aciculina sp. & $* *$ & - & $* * *$ & - \\
\hline 2 & Alvaniarykelii & $* *$ & $* *$ & $* * *$ & $*$ \\
\hline 4 & Bellamyabengalensis & $* * *$ & $* * *$ & $* * *$ & $* * * *$ \\
\hline 5 & Calliostomacoppingeri & - & - & $* * *$ & $* *$ \\
\hline 6 & Cerithideafluviatillis & - & - & $* * *$ & - \\
\hline 7 & Cerithideopsillaconica & $*$ & $* *$ & $* * *$ & - \\
\hline 8 & Circulusstriatus & - & $* *$ & - & $*$ \\
\hline 13 & Clathrofenella ferruginea & - & $*$ & $* *$ & $* * *$ \\
\hline 3 & Cylichna cylindracea & - & - & $* *$ & - \\
\hline 9 & Epitoniumapiculatum & - & - & $* *$ & $* * *$ \\
\hline 10 & Gibberula granum & - & - & $* * *$ & - \\
\hline 11 & Gibborissoa virgate & - & $*$ & $* *$ & - \\
\hline 12 & Japonactaeon pusillus & - & $* *$ & - & $* *$ \\
\hline 14 & Lymnaea teneraeuphratic & - & - & - & $*$ \\
\hline 15 & Odostomia impressa & $* *$ & - & $* *$ & - \\
\hline 16 & Odostomia serenei & - & - & - & $* * *$ \\
\hline 17 & Omalogyraatomus & - & - & $* * *$ & - \\
\hline 18 & Polynicesampla & $* * *$ & - & - & - \\
\hline 19 & Polynicesmamilla & $* * * *$ & $* *$ & $* * * *$ & $* *$ \\
\hline 20 & Pyramidellidae gen. sp. & $* *$ & - & - & $* * *$ \\
\hline 21 & Retusaobtusa & - & $* * *$ & $* *$ & $*$ \\
\hline 22 & Scaliola sp. & - & -- & $* * *$ & - \\
\hline 23 & Terebramaculata & - & $* *_{-}$ & $* * *$ & $* * *$ \\
\hline 25 & Turbinellapyrum & $*$ & $* * *$ & $* *$ & $* * * *$ \\
\hline 24 & Turbonillaobliquata & $*$ & $* *$ & $* *$ & $*$ \\
\hline 26 & Turbonillaumbrina & - & - & $* * *$ & - \\
\hline 27 & Umbonium sp. & $*$ & - & - & $* * *$ \\
\hline \multirow[t]{2}{*}{28} & Umboniumvestiarium & - & $* * *$ & $* *$ & - \\
\hline & $* * * *$ Abundant $\quad * * *$ Rich & $* *$ Little & $*$ Rare & -Absent & \\
\hline
\end{tabular}




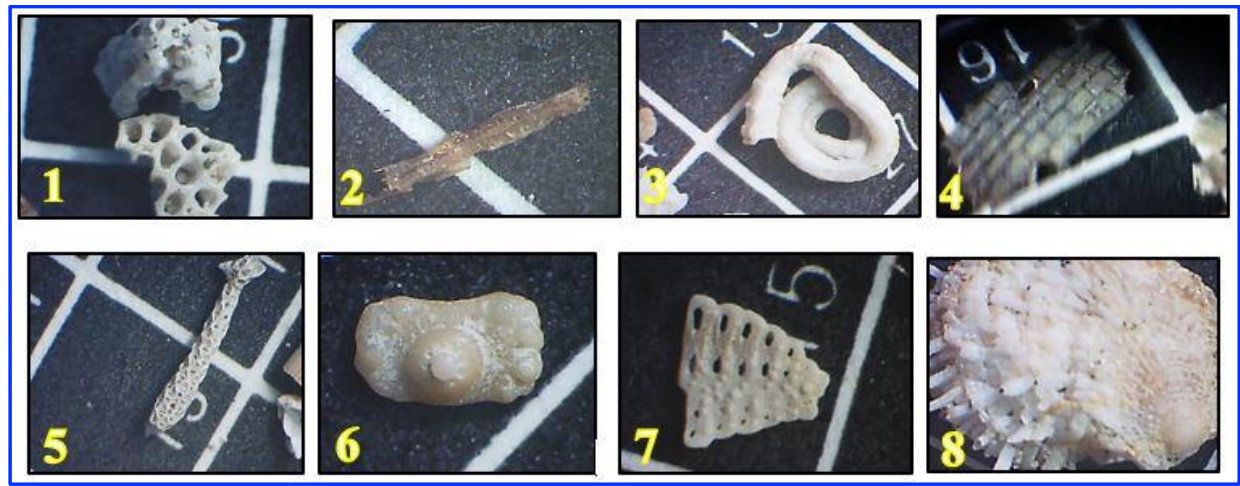

Plate 4. Bryozoa

1. Gymnolaemata (Allman, 1856) $15 \mathrm{X}$

2. Gymnolaemata (Allman, 1856) $25 \mathrm{X}$

3. Bryozoa sp.1, 18X

4. Hederella sp. (Hall 1883) $25 \mathrm{X}$
5. Bryozoa sp. $2,12 \mathrm{X}$

6. Bryozoa sp.3, 25X

7. Bryozoa sp.4, $18 \mathrm{x}$

8. Membranipora sp on Pelecypoda. 9x

Table 8. Pelecypoda distribution in the samples

\begin{tabular}{|c|c|c|c|c|c|c|}
\hline \multirow[t]{2}{*}{ NO. } & \multicolumn{2}{|l|}{ Sample No. } & 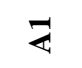 & $\underset{\pi}{N}$ & $\ll$ & $\underset{\nabla}{\nabla}$ \\
\hline & \multicolumn{6}{|l|}{ Species } \\
\hline 1 & \multicolumn{2}{|l|}{ Angulus sp. } & $* *$ & $* * * *$ & $* * * *$ & $* *$ \\
\hline 16 & \multicolumn{2}{|l|}{ Bassina callophyla } & - & - & $*$ & - \\
\hline 3 & \multicolumn{2}{|l|}{ Bassinayatei } & $*$ & $* * *$ & $* *$ & $* *$ \\
\hline 4 & \multicolumn{2}{|l|}{ Bentharcasagrinata } & - & $* *$ & $* *$ & $* *$ \\
\hline 5 & \multicolumn{2}{|l|}{ Brachyodontesvariabilis } & $*$ & $* *$ & $* *$ & $*$ \\
\hline 6 & \multicolumn{2}{|l|}{ Calyptraeachinensis } & $* *$ & $* *$ & $* *$ & $* *$ \\
\hline 7 & \multicolumn{2}{|l|}{ Carbulasubquadrata } & $* *$ & $* * *$ & $* * *$ & $* *$ \\
\hline 8 & \multicolumn{2}{|l|}{ Carditella pallid } & $* * *$ & $* *$ & $* * *$ & $* * *$ \\
\hline 9 & \multicolumn{2}{|l|}{ Codakia orbicularis } & $*$ & $* * *$ & $* * *$ & $* *$ \\
\hline 10 & \multicolumn{2}{|l|}{ Corbicula fluminalis } & $* * *$ & $* *$ & $* * * *$ & $* * *$ \\
\hline 11 & \multicolumn{2}{|l|}{ Crassostreairidescens } & $*$ & $* *$ & $*$ & $* * *$ \\
\hline 2 & \multicolumn{2}{|l|}{ Cuna majeeda } & - & - & $*$ & $* *$ \\
\hline 12 & \multicolumn{2}{|l|}{ Dosinia Laminata } & $* * * *$ & $* * *$ & $*$ & $* * *$ \\
\hline 13 & \multicolumn{2}{|l|}{ Hiatellaartica } & $*$ & $* * *$ & $* * * *$ & $* *$ \\
\hline 14 & \multicolumn{2}{|l|}{ Kelliasuborbicularis } & - & $* * *$ & $* *$ & $* *$ \\
\hline 15 & \multicolumn{2}{|l|}{ Mactra sp. } & $* *$ & $* * *$ & $* * *$ & $* * * *$ \\
\hline 17 & \multicolumn{2}{|l|}{ Musculusniger } & - & $* *$ & $* *$ & $* * *$ \\
\hline 18 & \multicolumn{2}{|l|}{ Ostrea sp. } & $*$ & $* *$ & $* *$ & $* * *$ \\
\hline 19 & \multicolumn{2}{|l|}{ Striarca lacteal } & - & - & $* * *$ & $* * *$ \\
\hline 20 & \multicolumn{2}{|l|}{ Tellina sp. } & $*$ & $*$ & $* * * *$ & $* *$ \\
\hline 21 & \multicolumn{2}{|l|}{ Theora mesobotimia } & $*$ & $* * * *$ & $* * * *$ & $* * * *$ \\
\hline 22 & \multicolumn{2}{|l|}{ Vasticardiumflavum } & $*$ & $* * *$ & $* * *$ & $* * *$ \\
\hline 23 & \multicolumn{2}{|l|}{ Vulsellavulsella } & $*$ & $*$ & $* *$ & $*$ \\
\hline$* * * *$ & Indant $\quad * * *$ Rich & $*$ Rare & & & & \\
\hline
\end{tabular}

Table 9. Scaphopoda distribution in the samples

\begin{tabular}{|c|c|c|c|c|c|}
\hline NO. & Sample No. & 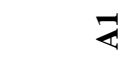 & $\underset{4}{N}$ & $\ll$ & $\underset{4}{\nabla}$ \\
\hline & Species & & & & \\
\hline 1 & Cidaris farringdonensis- urchin spine & $*$ & $* *$ & $*$ & $* * *$ \\
\hline 2 & Dentalium diarrhox & $*$ & $* * *$ & $* *$ & $* *$ \\
\hline 3 & Dentalium octangulatum & $*$ & $* * *$ & $* *$ & $* *$ \\
\hline 4 & Dentalium quadrapicale & $* *$ & $* * *$ & $* * *$ & $*$ \\
\hline \multirow[t]{2}{*}{5} & Dentalium sp & $* *$ & $* *$ & $* *$ & $* *$ \\
\hline & $* * * *$ Abundant & $* *$ Little & *Rare & ent & \\
\hline
\end{tabular}


Table 10. Bryozoa distribution in the samples

\begin{tabular}{|c|c|c|c|c|c|c|}
\hline \multirow[t]{2}{*}{ NO. } & Sample No. & \multirow[t]{2}{*}{ 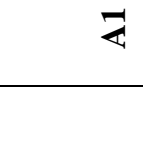 } & & \multirow[t]{2}{*}{ 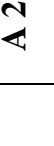 } & \multirow[t]{2}{*}{$\ll$} & \multirow[t]{2}{*}{$\underset{\leftarrow}{+}$} \\
\hline & Species & & & & & \\
\hline 2 & Bryozoa sp.1 & $* * *$ & & - & $*$ & - \\
\hline 4 & Bryozoa sp.2 & $*$ & & $*$ & $* *$ & - \\
\hline 5 & Bryozoa sp.3 & $*$ & & $*$ & $* *$ & $* *$ \\
\hline 6 & Bryozoa sp.4 & - & & - & $* * * *$ & $* *$ \\
\hline 1 & Gymnolaemata & - & & - & $* *$ & $* *$ \\
\hline 3 & Hederella sp. & $*$ & & $* *$ & $*$ & $*$ \\
\hline \multirow[t]{2}{*}{7} & Membranipora sp. & $* *$ & & $*$ & $* *$ & - \\
\hline & $* * * *$ Abundant $\quad * * *$ Rich & $* *$ Little & *Rare & \multicolumn{2}{|c|}{-Absent } & \\
\hline
\end{tabular}

The holes on some shells indicate that the animal has been exposure for preying from another animal for feeding, where the predator drills a hole in the Pelecypoda shell to absorb the soft part inside the shell, the widening hole could be caused by greater numbers and better nutritional value of prey species such as spiders and beetles and perhaps to minimize predators' vulnerability to their own enemies (Klompmaker et al. 2017) (Fig. 6).

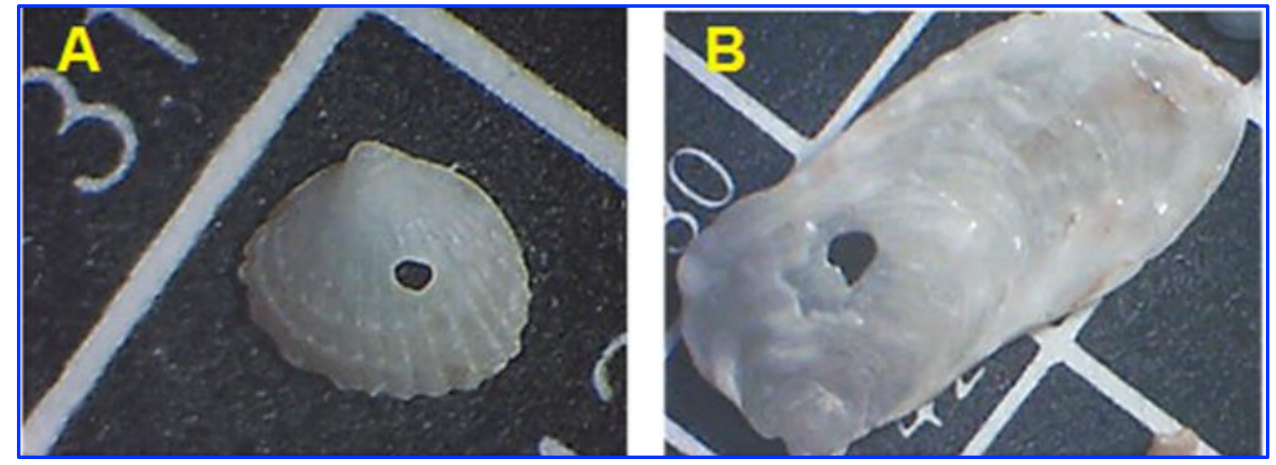

Fig. 6. Some of holes at the Pelecypoda shells (A-18X, B-9X)

\subsection{Sediments and Fauna}

The coral reef area is characterized by environmental factors which are suitable for the reproduction of fauna, coral and other marine organisms, on the other hand, the texture of sediments is also suitable for living, especially for benthic fauna. The high level of calcium carbonate in the water leds to the construction of shells significantly. Al-Humaidan (2018) indicated that there is a positive relationship between the quantity of shells and the percentage of $\mathrm{CaCO}_{3} \%$ where the amount of shells increased with increasing $\mathrm{CaCO}_{3} \%$ and depth, Moreover, she emphasized that the sandy and sandy silt texture is suitable for fauna, it has also been observed through this research that the Scaphopoda is living in sediment within the range of sand and sandy silt, but Jones and Baxter (1987); Spear (1994) has been found by them studied that Scaphopoda burrow in sediments ranging from muds to medium-coarse gravel. Where the oxygen content is sufficient for life (Table 4 and Fig. 7). The color of the shell is usually white, as it consists of calcium carbonate. There are many reasons for the coloring of the shells, the most important what Williams (2017) indicated that some of the main shell pigments found in Mollusca (carotenoids, melanin and tetra pyrroles, including porphyrins and bile pigments) and their durability in the fossil record, the evidence for the heritability of shell color in some taxa and recent efforts to understand the molecular mechanisms underpinning synthesis of shell colors and finally, the pigments appear to be distributed in a phylogenetically relevant manner and that the synthesis of color is likely to be energetically costly. 


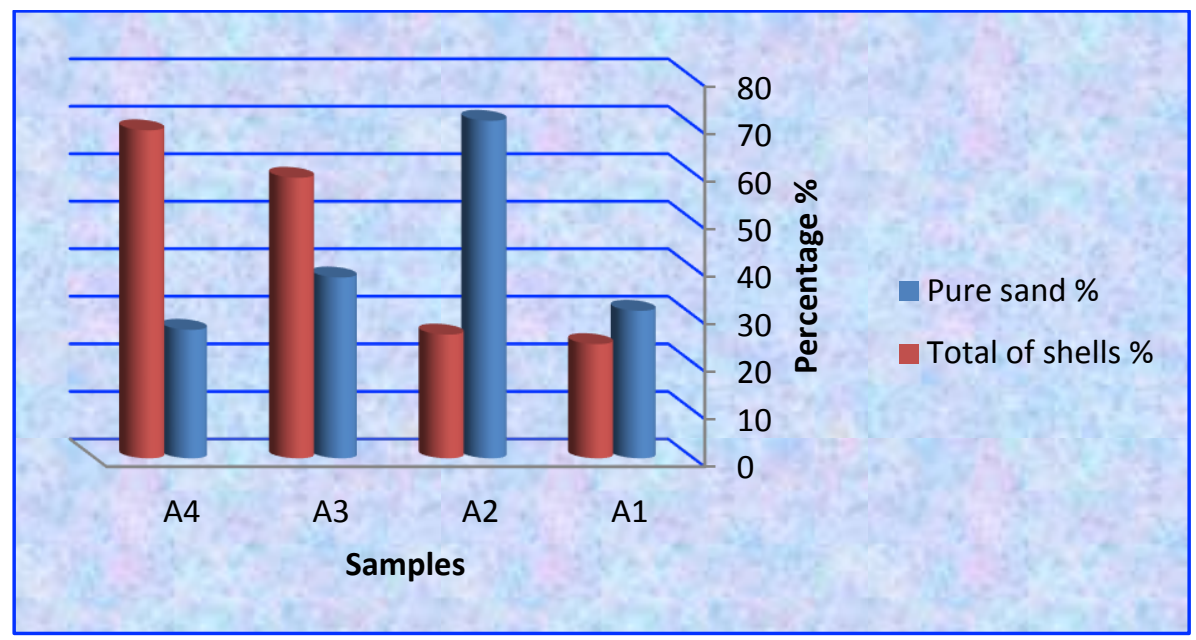

Fig. 7. The relationship between pure sand and total of shells

Coloration is dictated mostly by regimen and the water environment the fauna lives in. For example, some species of Gastropod that live and feed on coral have shells that take on the same color as the coral. There are high levels of oxides in the region, especially aluminum $\mathrm{Al}_{2} \mathrm{O}_{3}$, iron $\mathrm{Fe}_{2} \mathrm{O}_{3}$ and other oxides, in addition to the high concentrations of some trace elements in coral reefs and sediments of the region such as $\mathrm{P}_{2} \mathrm{O}_{5}$ (Al-Jabri et al. 2018). This reflects the pollution occurring in the area and leads to sand discoloration in several colors. Certain colors, particularly yellow shades, can be related to periods of lower stands of sea level when parts of the shelf were exposed to the air (Stanley, 1969). Cain (1988) showed that some coloration of some species shells was due only to staining by sediments. Shell color is also relevant to the interaction of Mollusca with their abiotic environment, in particular temperature, but has also been linked to other environmental factors (Cook and Freeman, 1986). Since the area is close to the Basrah oil port, the pollution will be significant as a result of the ships located near the port, this affects with the passage of time the colors of the shells in an attempt to adapt to the pollution of the environment in which they live. The study of sediments under the microscope and observation by eye detected a high percent of shell fragments in the region, and they were of large quantities, especially at the size of $0.50 \mathrm{~mm}$ (Table 3) and that's what the results of the study confirm by Al-Zlemat (2019).

\section{Conclusions}

- The area is characterized by fine sandy sediments, the texture was sand and sandy silt, and it is suitable for the growth and reproduction of fauna.

- There are many sand colors in sediments like white, yellow, light yellow, transparent, orange, brown and black, etc., due to the existing minerals, impurities, organic matter and pollution found in the area.

- Changing the shells colors may be due to genetic factors, high organic matter and pollution in the area, or feeding some species on coral reefs and change other environmental factors.

- The study area has been transformed from a turbulent current from the tides in the previous period into a calm environment, due to the environmental changes taking place in the area, this interprets the high percentage of shell fragments present in the sediment.

- The shape of the sand grains in sediments is mostly roundness to sub-roundness, and this indicates that they are transported from long distances.

- Environmental conditions such as temperature, depth, salinity, type of texture sediments, $\mathrm{pH}$ and availability of food helped in the diversity and abundance of fauna. 


\section{Acknowledgements}

The authors are very grateful to the Editor in Chief Prof. Dr. Salih M. Awadh, the Secretary of Journal Mr. Samir R. Hijab. and the Technical Editors for their great efforts and valuable comments.

\section{References}

Al-Ghadban, A., 1980. Recent shallow-water sediments in the area between Ras Al- Jalayah and Ras Al-Zour (Southern Kuwait). University of Kuwait. M. Sc. Thesis. University of Kuwait, 204pp.

Al-Humaidan, Z. A., 2018. Sediment Logical, Mineralogical and Fauna Study of Marine Sediments NW of the Arabian Gulf, Southern Iraq, M.Sc. Thesis, University of Basrah, 178 pp.

Al-Jaberi, M. H., Al-Dabbas, M. A., Bashar, A.G., Jaber, M.Q., 2018. Mineralogy and Geochemistry of Coral Reef in Iraqi Marine Environment in the north part of Arabian Gulf. Bull. Iraq natural History Museum, (2), 189-206.

Al-Jaberi, M., Mahdi, M., 2020. Mineralogy and paleontology of the Quaternary sediments in Karmat Ali at Basrah, Southern Iraq. Iraqi Geological Journal, 53 (2C), 105-120.

Al-Mosawi, W. M. (2015). Marine Geophysical Survey to Detect the Sea Bottom Morphology and Coral Reefs within Iraqi Borders Using Sub Bottom Profiler and Side Scan Sonar Techniques. Unpubl. PhD. Thesis, Science, Co. Baghdad, Uni. Iraq.

Al-Omari, F. S., Abadi, T. S., 1982. Petrology book, Books and Printing House, University of Mosul, 474 pp.

Al-Sudani, K. J., 2015. Geological study of Hareer's Tells, Southern Iraq. M.Sc. Thesis, University of Basrah, 129 pp.

Al-Zlemat, N. S., 2019. Sedimentological and Mineralogical Study of Palinurus Shoal in the Northwest Arabian Gulf. M. Sc. Thesis, University of Baghdad, Iraq.

Angela, B., Moline, S. A., Netzer, N., 2000. Fiddler crab rhythm and blues: Daily and tidal rhythms of UcaLeptodactyla in salt-water aquarium. University of Montana, 26-29.

Boggs, J. R., 2006. Principles of Sedimentology and Stratigraphy (4th edition). Pearson Prentice Hall. 634-662P.

Burns, K. A., Smith, J. L., 1981. Biological monitoring of ambient water quality: the case for using bivalves as sentinel organisms for monitoring petroleum pollution in coastal waters. Estuarine, Coastal and Shelf Science, 30 (4), 433-443.

Burt, J. A., Smith, E. G., Warren, C. S., Dupont, J. M., 2015. An assessment of Qatar's coral communities in a regional context. Marine Pollution Bulletin, 105(2), 473-479.

Cain, A. J., 1988. The colors of marine bivalve shells with special reference to Macoma balthica. Malacologia ,28, 289-318.

Claisse, D., 1989. Chemical contamination of French coasts. The results of a ten years mussel watch, 20, 523-528.

Coles, S. L., Riegl, B. M., 2013. Thermal tolerances of reef corals in the Gulf: a review of the potential for increasing coral survival and adaptation to climate change through assisted translocation. Marine Pollution Bulletin, 72, 323-332.

Cook, L. M.,Freeman, P. M., 1986. Heating properties of morphs of the mangrove snail Littoraria pallescens. Biological Journal Society, 29: 295-300

Folk, R. L., 1974. Petrology of sedimentary rocks. Texas, USA: Hemphill's, Austin, 128-182 pp.

Goudie, A. S., 2006. Encyclopedia of Geomorphology, vol-1, Taylor \& Francie's-library.

Hageman, S. J., Bock, P. E., Bone, Y., Mcgowran, B., 1998. Bryozoan growth habits: Classification and analysis, Abstract. Journal of Paleontology, 72(3), 418-436.

Jones, A. J., Baxter, J., 1987. Molluscs: Caudofoveata, Solenogastres, Polyplacophora and Scaphopoda. Society of London, $123 \mathrm{pp}$.

Karim, H. H., Salman, H. H., 1988. Geology of the Arabian Gulf. Publications of the Marine Sciences Center. University of Basrah, $330 \mathrm{pp}$.

Keen, A. M., Coan, E. V., 1974. Marine Mollusca genera of western North America 2nd ed. Stanford, California: Stanford University Press. 208 pp.

Khalifa, U. Q., 2019. Hydrodynamic of the sediment's movement in the Southern Part of the Shatt al-Arab and North-Western of the Gulf Basrah, Journal of Science, 37 (2), 237-251. 
Klompmaker, A. A., Kowalewski, M., Huntley, J. W., Finnegan, S., 2017. Increase in predator-prey size ratios throughout the Phanerozoic history of marine ecosystems. American Association for the Advancement of Science, 365 (6343), 1178-1180.

Moore, R. C., 1969. Treatise on invertebrate paleontology, Part N, Mollusca 6 Bivalvia. Geological society of America and The University of Kansas, 989 pp.

Perkol-Fenkel, S., Banayahu, Y., 2007. Deferential recruitment of benthic communities on neighboring artificial and natural reefs. Journal of Experimental Marine Biology and Ecology, 340, 25-39.

Pohel, T., Al-Muqdadi, S.W., Ali, M. H., Al-Mudaffar, N. F., Ehrlich, H., Merkel, B., 2014. Discovery of a living coral reef in the coastal waters of Iraq. Scientific Report.

Selley, R. C., 1982. An Introduction to Sedimentology, Academic Press INC. $2^{\text {nd }}$ ed., London, 417pp.

Shareef, N. F., Mahdi, M. M., 2015. Studying of recent environments in Faw, Khor Al-Zubair and Um-Qaser areas, Southwestern Arabian Gulf, Basrah, Iraq. Journal of Basrah Researches (Sciences), 41 (2), 1-14.

Shareef, N. F., Khalifa, Q. U., Shubar, I. Y., 2015. The salinity effect and sedimentary types for the fauna distribution during the Holocene in Southern Iraq. Mesopotamian Journal Marine Science, 30(2), 124- 141.

Spear, B., 1994. Introduction to the Scaphopoda, the tusk shells (On-line).

Stanley. D. J., 1969. Atlantic Continental Shelf and Slope of the United States-Color of Marine Sediments. Geological Survey Professional Paper 529-D. United States Government Printing Office, Washington. D1.

Varghese, T. I., 2014. Sedimentology and Geochemistry of core sediments from the Ashtamudi Estuary and the Adjoining Coastal plain CentralKerala, India. Ph. D. Thesis, University of Science and Technology, 69 pp.

White, M. M., Chejlava, M., Fried, B., Sherma, J., 2007. The concentration of calcium carbonate in shells of freshwater snails. American Malacological Bulletin, 22 (1), 139-142.

Williams, S.T., 2017. Molluscan shell colour. Biological Reviews, 92(2), 1039-1058.

Zuschin, M., Hohenegger, J., Steininger, F., 2001. A comparison of living and dead Molluscs on coral reef associated hard substrata in the northern Red Sea-Implications for the fossil record. Paleogeography, Paleoclimatology, Palyoecology,159 (1-2), 167-190. 